\title{
Thinking Spirituality Differently: Michel Foucault on Spiritual Self-Practices, Counter-Conducts, and Power-Knowledge Constellations
}

\section{Herman Westerink}

Titus Brandsma Institute/Center for Contemporary European Philosophy, Faculty of Philosophy, Theology and Religious Studies, Radboud University, P.O. Box 9103, 6500 HD Nijmegen, The Netherlands;

h.westerink@ftr.ru.nl

Received: 23 December 2018; Accepted: 26 January 2019; Published: 28 January 2019

\begin{abstract}
In contemporary debates on the so-called "return of religion" in new forms and practices of spirituality, the spiritual practices are often seen as emerging on the ruins of a fragmented and outdated religious tradition. In this article an attempt is made to conceptualize spirituality beyond the religion-secularization divide. An alternative perspective on spirituality is developed through a reading of Michel Foucault's writings and lectures on spiritual practices in antique philosophy and in Christianity. In this perspective the modalities of individual spiritual practices are largely dependent on interactions with dominant power-knowledge regimes and problematizations of individual lives. This article argues that this perspective on the spiritual practices in the West has the potential of making a valuable contribution to interpretations of present-day spirituality and lived religiosity.
\end{abstract}

Keywords: foucault; spirituality; religion; counter-conduct; self-practice; hermeneutics of the subject

\section{Introduction}

In the contemporary literature on the so-called "return of religion" or the "religion in transformation processes" the interpretations of the concept and phenomenon of spirituality play a crucial role. Notably the various ways in which the relation between religion and spirituality can be articulated have drawn attention from sociologists and psychologists of religion, scholars in religious studies, theologians, and also philosophers. There are, for example, the intriguing and puzzling self-identifications of people in terms of "being spiritual and religious" or "being spiritual but not religious" (for example (Streib 2008; Streib and Hood 2011; Mercadante 2014)). Such self-identifications point towards a complex domain composed of various entangled discourses in which spirituality has very different meanings and associations. It has been noticed that the first of the two self-identifications (and two options a broader range of varieties) can be linked to a religious discourse on spiritualité that emerged first in France in the late nineteenth-century. Against the background of discussions on religious experience and mysticism in Protestant theology, of the need to counter the tendency in psychiatry and neurology to associate spiritual phenomena such as mysticism and demonic possession with pathology (notably hysteria), and of the need to highlight spiritual experiences and practices relative to the dominance of speculative Neo-Scholastic thought in Catholic theology, a discourse on spiritualite emerged in which one sought to restore the balance between the lived faith of individuals as the vital and dynamic core of the religious tradition on the one hand and the church teachings and institutions on the other hand. In this line, spirituality is at the heart of religion itself, even though the spiritual experiences and movements-more concrete, the mystical and ascetic experiences and practices—had often had a "subversive" character vis-á-vis the official teaching and institutions (Talar 2009; Kugelmann 2011). The second of the two self-identifications much more points towards a discourse on spirituality in the Anglo-Saxon world. Here, spirituality 
refers to a variety of sources and trends-such as an interest in Eastern spirituality, esoteric practices, theosophy, etc.- that in the 1960s were packed under the heading of the "New Age movement". This movement was easily associated with a firm critique and dismissal of traditional but are now seen as "outdated" religious institutions, authorities, doctrines, and practices (Heelas and Woodhead 2005; Aupers and Houtman 2008; Bregman 2014; Westerink 2016). At first sight, a "genealogy of spirituality" does not lead much further back than the late nineteenth century, and the various reflections on how spirituality/spiritualité might or should replace, transform or revive the religious domain. This implies that there is seemingly no other way of conceptualizing spirituality than in its relation to religion, modernity, and secularization.

At this point, one might raise the question whether it is self-evident that spirituality is often exclusively thematized in relation to more or less recent secularization and individualization processes. For, one could also argue that the rise of spirituality as discourse in the twentieth century and the subsequent self-identification relative to religion can be situated in a broader context of historical developments in the West. Processes of so-called individualization, pluralization, and privatization - often mentioned as characteristics of spirituality-do not first emerge in the protest movements of the 1960s, nor do they stem from the Romantic period and the turn to the "authentic" and "true" self and its in-depth and therapeutic self-explorations. They can at least be linked to "the turn to the subject" in early modernity, that is more concrete, to the Cartesian subject that defines itself as an autonomous subject (res cogitans) with a capacity for having objective knowledge of reality and for composing a consistent and meaningful worldview. Scholars such as Marcel Gauchet and Charles Taylor trace the sources of individualization and privatization even further back in history arguing that as early as in the axial age there is a first tendency towards individualization in religion as result of new representations of a transcendent divine reality towards which each individual should orient his/her life (Gauchet 1997; Taylor 2007).

A project of a "genealogy of spirituality" tracking the origins and formation of individualized spiritual practices and experiences in line with these authors thus moves far beyond the late nineteenth century and the actual emergence of a new discourse on spirituality/spiritualité. It is from this that we can begin to think of spirituality differently, that is, no longer in relation to an autonomous, "buffered" or detached consumerist individual that in its practices of "sacralization of the self" (Aupers and Houtman 2008) is actually a symptom of an ongoing de-traditionalization and erosion of former more or less stable religious, social, and political orders (comp. Taylor 2008, p. 144). Maybe spirituality should not exclusively be linked to a past century of secularization and individualization processes. One could instead formulate the hypothesis that in the Western tradition, starting with Greek philosophy (since the axial age), a notion of the necessity of an individual-oriented spirituality relative to political, social, and religious practices and institutions has always been recognized as vital for the formation of these political, social, and religious structures on the one hand, and as problematic because of the critical potential of spirituality in relation to already established institutions and doctrines on the other hand. The Western philosophical and religious tradition is strongly shaped by the ongoing interactions between individual spirituality and political, religious and social discourses and institutions. The question then is not so much whether and how spirituality is or represents the "religious after religion" (Gauchet 1997), but how spirituality is articulated and transformed when relocated in and through the political, social, religious, and economic discourses and structures that we can identify in contemporary society. ${ }^{1}$

1 Such perspective on new forms of spirituality relative to competing secular and religious discourses finds support in the thesis brought forward by Houtman, Aupers, and De Koster (Houtman et al. 2011) that the individual's allegedly authentic and unique spiritual ideals, experiences, and practices and the very personal quests towards a "true" and "deeper" self (Heelas 1996, p. 19), are in fact manifestations of underlying shared beliefs, of a doctrine of individualism that is legitimized by a multiplicity of institutions, social environments, and organized practices that aim at forms of control over and profit from the individual's care for and engagement with its self (see also Houtman and Tromp 2018). 
In this paper I would like to explore Michel Foucault's views of spirituality in order to show that (1) spirituality as it appears in the West has always been and still is established around the individual's quest for truth through spiritual self-practices; and that (2) spirituality throughout Western history is a highly contested phenomenon, a domain of practices and experiences that (a) goes hand in hand with critique of organized forms of power and knowledge; (b) is seen as vital for the formation of (new) political, social, and religious structures; and (c) is for this reason also the preferred domain of intervention and problematization of the individual from the side of doctrinal knowledge and power structures. The general claim of this article is that Michel Foucault's views on the relation between antique and early Christian spiritual self-practices and power-knowledge regimes have the potential of providing valuable perspectives on the contemporary spirituality as a multiplicity of new constellations of practices of self-mastery, hermeneutics of the self and accesses to the truth relative to power-knowledge regimes-constellations that are deeply rooted in the Western spiritual and intellectual tradition.

\section{Antique Practices of Self-Mastery as Spirituality}

In this course on "the hermeneutics of the subject" from 1981-1982 Foucault aims to explore the relations between subject and truth as they take shape in the West (Foucault 2005, p. 2). The reason for making this question a central one in his project of a history of sexuality can be found in the insight that the production of subjects, more concrete of sexual identities, cannot be fully explained from an organization of disciplinary power and knowledge in the scientia sexualis. For, such production of subjects through subjection (assujettissement) cannot do fully justice to the fact that subjects also constitute themselves as moral subjects, as moral agents, through all kinds of available techniques and practices, and recognize themselves as moral agents that can orient their own lives and actions-their moral attitude and ethos-towards what they would consider the truth. According to Foucault, this is a process of subjectivation (subjectivation) that takes the form of a permanent relationship to the self (Foucault 2017, p. 284). Such subjectivations are not set apart from processes of subjection and domination, since the self-constitution is always based on the patterns and models strategically suggested by a cultural context, hence, by existing power-knowledge organizations. But at the same time, these subjectivations are not subjections in disguise: there is a relative independence and a possibility of individual tactics and singular acts that guarantees critical self-reflection, moral freedom, and responsibility, the ethical work upon oneself, and ultimately also a critique of power-knowledge regimes (Oksala 2005, p. 165).

Such subjectivation, such relationship of the self with the self, starts from a "care of the self". From Platonic thought onwards the form the self-constitution should have is predominantly formulated in terms of the subject's relation to knowledge and truth. Self-knowledge, that is to say, knowledge of the truth of oneself, becomes the preferred form of the care of the self. According to Foucault, the notion of care of the self is crucial for understanding antique philosophy and "spirituality". The care of the self-epimeleia heautou-takes a central place in Plato's Alicibiades and notably also in Stoic literature (Seneca, Epictetus). It always "designates a number of actions exercised on the self by the self, actions by which one takes responsibility for oneself and by which one changes, purifies, transforms, and transfigures oneself" (Foucault 2005, p. 11). Another way of describing this care of the self is through the notion of "spirituality", a term that evidently stems from a Christian discourse we have already associated with a (re)-discovery of the experiential-mystical and ascetic-aspects of the Christian tradition, and that Foucault now uses to further specify the care of the self:

"We will call 'spirituality' then the set of researches, practices, conversions of looking, modifications of existence, etc., which are, not for knowledge but for the subject, for the subject's very being, the price to be paid for access to the truth". (Foucault 2005, p. 15)

For Foucault, this "spirituality" is no longer limited to the notion of spiritualite relative to the Christian tradition, let alone to the "spirituality" as it emerged from the nineteenth century onwards 
as an alternative to religious institutions and doctrines and theological rationalizations. For Foucault spirituality first of all points towards the care of the self and the "ascetic" self-practices that in antique philosophy are seen as practices of self-constitution and self-stylization through complex self-transformations that will bring the subject in the position of having access to the truth.

The late writings of Foucault, starting with the courses on subjectivity and truth (1980-1981) and the hermeneutics of the subject (1981-1982), and culminating in the volumes two and three of The History of Sexuality-The Use of Pleasure and The Care of the Self-published in 1984, which are by and large explorations of Greek and Roman spiritual practices and exercises of self-mastery. In these writings Foucault shows that antique philosophy is not about the production of ideas and doctrines, not about the formulation of general rules, procedures and laws, but about practices of self-mastery. Antique philosophy is a practical-moral philosophy in which the individual's objective is mastery over needs, passions, and pleasures that, if not mastered and controlled, enslave the individual, i.e., turn the potentially free and active moral agent into a passive slave of his own inclinations. This mastering and controlling of the needs, passions, and pleasures takes the form of self-limitations and renunciations in order to achieve an optimum of enjoyment and to avoid excessive indulgences (Foucault 1990, 1992, 2005, 2017).

Spirituality as self-mastery and self-constitution: the patterns and models, exercises and techniques, are offered by an aristocratic elitist cultural environment that, if we follow Foucault's reading of Plato's Alcibiades (Foucault 2005, chp. 2-5), sees the care of the self and the self-mastery as preconditions for care of others and the mastery of others in the polis. Spirituality is a precondition for a proper engagement in the political realm and for taking responsibility for the laws and rules that organize the polis; and the person that constitutes a truthful relation with itself through knowledge will also be able to convincingly communicate the truth in the political arena. From this we can begin to understand Foucault's interest in the cynic tradition, because notably—and maybe even only-the cynics are both free and autonomous masters of themselves as well as critics of the actual politics and societal conventions in the polis. In other words, it is notably the cynics that fully develop a self-mastery that goes hand in hand with a critique of the way people lead their lives in this world. Beyond self-mastery, their aim is to show their fellow men "another way of living" (vie autre) that will eventually result in "a world that is other" (monde autre)-hence, they use their freedom through self-mastery for a critique of established and seemingly self-evident power-knowledge regimes (Foucault 2011, pp. 245-47). The cynic spirituality includes the critique of societal conventions and political mismanagement.

\section{Christian Hermeneutics of the Self and the Problem of Subjection}

"Between the philosophical exercise and Christian asceticism there are a thousand years of transformation and evolution in which the care of the self is undoubtedly one of the main threads". (Foucault 2005, pp. 11-12)

According to Foucault in his late writings, the transition from antique philosophical spiritual practices to Christian spirituality cannot be described in terms of an epistemic shift or rupture, but should be seen as a complex series of modifications and refinements concerning "the arts of living and the care of the self" (Foucault 1990, p. 239). In order to study this transition, Foucault indeed does not focus on the laws and rules expressed in moral ideas, nor does he focus attention on the question how individuals relate to moral prescriptions. Instead he inquires into the techniques and practices through which the subject constitutes himself as a moral agent (Foucault 1992, p. 25ff). In a series of articles and lectures from the late 1970s and early 1980s, culminating in the recently published fourth volume of The History of Sexuality, Les aveux de la chair, Foucault describes how in early Christianity the antique forms of care of the self, notably Stoic self-practices and thought, are continued in early Christianity (Foucault 2018, pp. 9-51). In fact, he argues that "a certain number of ascetic themes ordinarily attributed to Christianity" (Foucault 1997a, p. 270) are born and developed from antique care of the self and self-practices that involve austere renunciations (enkrateia), self-restraint and 
moderation (sophrosunè). In other words, at this point there is no rupture, but continuity between antique and Christian spiritual practices.

However, Foucault also argues that Christianity does introduce new and decisive elements in the care of the self that as such cannot be found in antique practices. The first aspect he mentions concerns a new idea of the self as intimately linked to "evil" and "original sin", that is to say, a notion of the self that is in principle opposed to God's will, and that for this reason has to be renounced. Whereas the antique philosophical schools held that the self-renunciation and moderation was necessary in view of self-mastery and the self-constitution "as a work of art" (Foucault 1997a, p. 271), of a craftsmanship that would permit the subject to live better and more free and happily, Christianity-more concrete, Tertullian-introduces the idea of self-renunciation relative to a notion of salvation and purification from sin and evil. Whereas Stoic self-practices, for example, were concerned with a self-mastery characterized by an indifferent attitude towards external impulses, Tertullian introduces a concept of "threat" that does not coincide with external impulses or forces, but is in fact engraved as an "impurity" in the deepest and darkest layers of the soul. The care of the soul now takes the form of a detailed hermeneutics of the deepest and most hidden "truth" in the human soul, that is, its sinful egoism and disobedience vis-à-vis God. Notably in his writings on penitence and baptism, Tertullian builds new relations between the teaching of the truth (doctrine), the adherence to the truth in acts of faith, and the acceptance of this truth as bearing upon the subject (exomologesis-confession), and a series of practices aimed at purification through self-examination and the confession (exageuresis-aveu) of the truth about oneself (Foucault 1999a, pp. 154-81; 2018, pp. 52-77).

Christianity introduces a notion of a highly problematic "truth" that lies hidden in the dark corners of the soul. The care of the self and the self-knowledge take the form of a "hermeneutics of the self", a careful and meticulous self-deciphering of the movements, impulses, passions, inclinations, urges, and "titillations" of the soul. These hermeneutics of the inner movements is the self-practice of "distrust", self-problematization, and of close combat with oneself in order to purify the soul of its "original evil". At least partly, these hermeneutics can draw upon antique Stoic exercises of deciphering one's motives, passionate reactions and perceptions. More importantly, however, is a fundamental reconsideration of the techniques of self-mastery in light of the problem of evil hidden in the dark corners of the soul. How does one master oneself if one is fundamentally disobedient towards God's will? Foucault will argue that this problem was tackled in early Christian monasticism. Here the hermeneutics of the self is conditioned by the strictest possible rules of obedience and subjection to the will of a spiritual master-a will that demands "the confession of the flesh". The self-mastery is transformed into a practice of absolute obedient subjection to the master-the "epimeleia heautou" now becomes "epimeleia tòn allòn", a pastoral care of the self by the other (Foucault 1997a, p. 278; 1999b, pp. 188-97; Foucault 2007, pp. 163-85; 2018, pp. 121-27).

What exactly is deciphered in this hermeneutics of the self, and what exactly is articulated in the confession of the flesh? In Foucault's inquiries into early Christianity two authors are central: John Cassias as the founder of the monastic tradition of "epimeleia tòn allòn" and the pastoral power demanding confession of the hidden libidinal and passionate movements of the soul, and his contemporary Augustine and his theory of original sin as disobedience, libido, and concupiscentia, and a hermeneutics of the self in relation to objectified laws and rules of the proper attitudes and conducts. Augustine is the towering figure in a "genealogy of the desiring subject" (Foucault 1992, p. 5) - a genealogy that is at the heart of Foucault's project of the history of sexuality. After all, in the first volume from 1976 Foucault had raised the question why the sexual revolution had taken the shape of a discourse that claimed the liberation of sexual desire and free speech over centuries of repression. This discourse was officially legitimized by structuralist approaches in cultural anthropology (Lévi-Strauss) and psychoanalysis (Lacan) that saw a dialectics of repressive law and desire at the origin and heart of cultural and psychic life (comp. Foucault 1998a, p. 109). Foucault's critical analyses led to another thesis: instead of repression the Christian and secular power structured had actually demanded an ongoing confession of sexual desires (Foucault 1998a, pp. 15-73). The question then is how and when in Western culture the subject had learned to recognize itself as a 
subject of a desire that was fundamentally problematic in its relation to the law. Foucault's ultimate answer in Les aveux de la chair was: Augustine (Foucault 2018, pp. 325-61).

Foucault's explorations of early Christianity produced insights in the formation of a Christian spirituality that can no longer be defined in terms of antique ascetics of self-mastery and self-stylization. Instead, a hermeneutics of the self is set in place relative to notions of obedience, subjection, and the law.

However, in analogy to Foucault's critique of popular views on sexual repression and liberation, one cannot simply conclude from the analyses of early Christianity that the Christian culture was until recently nothing but a repressive culture that demands subjection to authorities, institutions, and doctrines. In fact, the Christian hermeneutics of the self and the inner explorations, examinations and purifications of one's desires can be seen as the origin of the modern and contemporary self-explorations and re-orientations of desire through spiritual experiences and practices. The idea that such contemporary spirituality would be conditioned by the "liberation" from outdated "repressive" religious institutions, authorities and doctrines is from a Foucaultian perspective likely to be misleading. Instead, what we learn from Foucault is that contemporary spiritual self-examinations can be situated in a long history of "care of the self", of antique ideals of living a truthful and authentic life, but also in a tradition of the Christian problematization and re-orientations of inner life through disciplined, careful, and often painful decipherment of the "deepest" and "truest" movements of the soul.

\section{Counter-Conducts and Parrhesiastic Practices: Spirituality as Resistance}

Although Foucault notably in his analyses of Cassian's writings on the pastoral care and confession in early monasticism focuses attention on the organization of a pastoral power in the West from which later emerged the modern political, societal and scientific structures of power and knowledge aimed at the control over populations (biopower), Foucault realizes already in the late 1970s that Christianity cannot be reduced to pastoral power regimes that merely demand subjection. The hermeneutics of the self as the new form of an antique care of the self is not simply the effect of productive pastoral regimes that make people confess. Quite to the contrary. As early as the 1977-1978 lectures on security, territory, and population, Foucault argues that Christianity not only developed models for pastoral power on which later regimes of governmentality could build, but also produced counter-conducts and forms of resistance vis-à-vis the pastoral power and the duty of subjection to spiritual authorities. On the one hand, indeed, the history of Christianity in the West from the days of the monastic definitions of pastoral power is marked by struggles over the pastoral power, notably in the Reformation and Counter-Reformation (Foucault 2007, pp. 149-50, 229). The relationship between religion and secular politics in the West is not found in the interplay between church and state, but "between the pastorate and government" (Foucault 2007, p. 191). Yet, on the other hand, there is also a certain continuity between the antique self-practices that do not demand obedient subjection to a spiritual master and the Christian spiritual tradition. Throughout the history of the pastorate there were spiritual counter-conducts that undermined and eventually fragmented pastoral power (in early modernity). In addition, it were these spiritual counter-conducts that then-while gradually taking more secular forms-became the preferred objects of governmental control which includes not only political institutions in the strict sense, but notably also psychiatric and penal institutions, educational, and even religious institutions in as far as they could be made into an instrument for the moral formation of civilians.

Where do we find these counter-conducts? According to Foucault, they main forms of counter-conduct can be found in the key spiritual movements in Christianity, that is to say, in asceticism and mysticism. Foucault defines ascesis in this context as "an exercise of self on self $(\ldots)$ in which the authority, presence, and gaze of someone else is, if not impossible, at least unnecessary" (Foucault 2007, p. 205). One finds this ascesis (askèsis) already in antique philosophy, but also in the earliest Christian spiritual models of the martyr, the virgin, and the hermit-the models that preceded the monastic ideal. But also, after the introduction of the monastic asceticism through obedience, 
various ascetic practices remain present and productive throughout the Christian history, notably in medieval spiritual movements such as the devotio moderna or the flagellant movements, and in the Protestant ascetics of self-discipline. To a large extent these are ascetic forms of self-mastery without interference by pastoral power (Foucault 2007, pp. 204-8).

Something similar can be set about the mystic tradition that starts as early as Origenes and Gregory of Nyssa (who in their own ways build on antique models of spiritual exercises) and is continued way into modernity. Like ascesis, mysticism dismisses pastoral intermediacy, when claiming a direct and immediate access of the truth (God) by the subject. In mysticism there is an immediate communication between the subject and the divine (Foucault 2007, pp. 212-13).

In later writings Foucault will return to this issue of the spiritual counter-conducts, but with a change of perspective. The ascesis and mysticism are not so much counter-conducts, i.e., reactive (and ressentimental or transgressive) resistances against the pastorate. They are-more positively formulated-a productive tradition of more or less free, critical, and autonomous subjects that "speak truthfully" and that confidently establish themselves in "a face-to-face relationship with God" (Foucault 2011, p. 337). In these last lectures, Foucault does not insist on the continuity between Stoic exercises of self-mastery and early Christian practices, but on a certain continuity between the cynic practice of parrhèsia, of free and frank truth-telling, with the aim of manifestation of another more truthful way of living (vie autre) in a world that other (monde autre). The mystic and ascetic currents in which this parrhesiastic element comes to the fore are notably present in early modernity, that is, in the era of spiritual fragmentation that sees the rise of secular power regimes trying to organize control over the individual's extraordinary and "irrational" spiritual truth claims. Mysticism in particular becomes something suspicious-irrational, maybe pathological and above all difficult to control by both religious and medical institutions (compare Foucault 2003, chp. 8).

\section{Philosophy and Science versus Spirituality}

In his lectures on the hermeneutics of the subject Foucault argues that in Plato we find two principles that will dominate Western thought. On the one hand, we find a notion of spirituality, that is to say, the idea that only through a series of transformative practices (askèsis) based on care of the self and aimed at self-knowledge a person can have access to the truth. On the other hand, it is the focus on self-knowledge that is the origin of the idea that only through rational and objectifying thought access to the truth is guaranteed. This principle is in fact "anti-spiritual", since objectifying rational thought does not necessarily imply transformative spiritual practices. In fact, as Foucault had already argued in earlier texts, it is from the second principle that the Western scientific tradition will emerge (Foucault 2005, pp. 77-78). Scientific "disciplines" and their organizations around "truths" that one should adhere to are rooted in a Western tradition founded in Platonic thought. The "Platonic" tradition is a tradition of rationalization relative to the notion of the universal truth and the "obligation to think 'in common' with others", that is, with other "knowing subjects" (Foucault 1998b, pp. 353-56). According to Foucault, what is at stake here is "the question for the West": the question of the status of the truth, more precise, the question why the concern for and obligation to truth overpowered the pluriformity of experimental practices, modifications of the subject and modes of thinking differently in such a way that the philosophical ethos could "only occur through the concern for truth" (Foucault 1997a, p. 295)? It was in this Platonic "climate" that the Western rationality was developed, and that "a movement of knowledge developed, a movement of pure knowledge without any condition of spirituality", or more precisely, without any condition of another kind of practice of "care of the self" and mode of thinking than a pure and objectifying knowledge of oneself (Foucault 2005, pp. 77-78). According to Foucault, here we find the origins of a principle from which eventually Descartes will give the official approval and the modern sciences will emerge.

On several occasions, Foucault argues that in Descartes the tension between the spiritual and the rational knowledge principle found in Plato culminates in a break with spirituality. The Cartesian Meditations the pursuit of knowledge and access to the truth is no longer conditioned by spiritual 
practices. For, although the Meditations are meditations (comp. Foucault 1998c, pp. 393-417), i.e., spiritual exercises, in the Meditations Descartes actually shows that spiritual self-transformations are redundant for finding true and certain knowledge. After all, the very fact that man is res cogitans implies that every rational being always has access to certain knowledge of the truth about himself and the external reality (Foucault 2005, pp. 1-14). In short, it was Plato who laid the foundations for "the constant climate in which a movement of knowledge (connaissance) developed, a movement of pure knowledge without any condition of spirituality" (Foucault 2005, p. 77), and it was Descartes who first drew the radical consequences when qualifying rational thought as the sole condition for having access to the truth.

According to Foucault, Descartes Meditations (as situated in the broader context of developments in early modernity) do not mark a definitive break between philosophy and theology, but between philosophy and spirituality. In fact, one could argue that theology will further develop analogous to modern philosophy, that is to say, as a scientific discipline that not necessarily involves spiritual practices. Theology and philosophy will both be shaped by the Platonic-Cartesian principles of the movement of knowledge, rational and objectifying thought, and the obligation think in common with others that participate in a particular scientific discipline. Descartes is the starting point for the various modern sciences—including philosophy and theology—as disciplines. Of such disciplines Foucault writes in The Discourse on Language:

“( ... ) disciplines are defined by groups of objects, methods, their corpus of propositions considered to be true, the interplay of rules and definitions, of techniques and tools: all these constitute a sort of anonymous system, freely available to whoever wishes, or whoever is able to make use of them, without there being any question of their meaning or their validity being derived from whoever happened to invent the." (Foucault 1972, p. 222)

Scientific knowledge is always disciplined knowledge. The knowledge does not demand from its subjects a specific mode of being, a way of living that was constituted through a series of transformative spiritual practices. To the contrary, while being freely available it merely demands adherence to "truths" (propositions, methods, rules, definitions) of the system. What does this imply? It implies that the subject freely submits to the already established organization of knowledge and power in discursive practices and hence also to "a system of prohibitions and values" producing exclusions and limitations, resistance effects, and transgressions. It is precisely in view of this ethical dimension of the scientific discourses in their quest for true knowledge that the question must be raised of whether the subject involved in these "ways of speaking" - the scholars (philosophers, theologians, and others)—should find ways to think and speak differently (Foucault 1972, pp. 192ff).

This question is taken up in later texts such as "What is Enlightenment?" and The Use of Pleasure when Foucault argues that philosophy should resist "the blackmail" of the modern scientific era that links the advancement in intellectuality and humanism to the emergence of various types of institutions and projects of rationalization, that is to say, to specific hierarchical organizations of power and knowledge. Instead philosophy should seek to develop a "limit-attitude" in which it critically reflects on the contingency and normativity of the boundaries between systems of knowledge and what is excluded from them. Obviously such critique cannot produce new "formal structures with universal value" that could replace outdated ones. Philosophy should not seek refuge in old or new ideologies. Rather, it should firstly problematize the kind of subjects produced by such formal structures, that is, the kind of scientifically disciplined subjects that do research, and think, talk and write "scientifically" and "scholarly". According to Foucault, this implies practicing a "philosophical ethos", meaning that one has to "carry work out by oneself upon oneself as free beings" (Foucault 1997b, pp. 312-16). For this reason, philosophy should reclaim its spiritual aspect, namely the "ascesis", i.e., "an exercise of oneself in the activity of thought" (Foucault 1992, p. 9). 


\section{Revisiting the Religion-Spirituality Divide}

In the contemporary debates on religion, spirituality, modernity, and secularization, it has been argued that one finds various positions as to how the emergence of spirituality relates to institutionalized religion and rationalization processes (Aupers and Houtman 2008). With regards to the relation with institutionalized religion, spirituality is often associated with a critique of established institutions and authorities. ${ }^{2}$ With regards to rationalization processes, on the one hand, the decline of traditional religious beliefs has been associated with ongoing rationalization processes in secular societies, while on the other hand the rise of spirituality has been linked to a critique of rationalism in the sciences, including philosophy and theology, and rationalization processes in society. Foucault's writings on (1) the Platonic "blueprint" for the tension between spiritual practices and procedures for rational knowledge, on (2) the Christian models for the relation between hermeneutical-ascetic practices and institutionalized pastoral power, and on (3) the modern spiritual practices (mysticism, asceticism) in relation to religious and secular (political, psychiatric, psychoanalytic) constellations of power-knowledge, may offer an interesting perspective on the contemporary spirituality.

On a more concrete level, the emergence of contemporary spiritual practices can be witnessed in several domains. I will briefly mention three such fields. Firstly, there is the rise of spirituality in the context of management practices. Here, we could argue, spirituality is introduced as a tool for optimization of the human resources and functionality: the spiritual practices (courses in meditations, introspections, etc.) serve the articulation of one's "truest" motivations, aims and ideals, producing a self-knowledge and consciousness that can be made productive in management styles and strategies. Secondly, there is the emergence of spirituality on the level of fundamental reflections on the "identity" and "core values" of institutions that were formerly associated with the established religious confessions. One can think here for example of spirituality in the context of education and the reflection on the "identity" of a certain school or group of schools. Thirdly, there is the complex field of spirituality in health care. Here, spiritual practices are introduced both to support physical health (yoga practices for example) and psychic health. In the past decades we have seen the emergence of numerous forms of "self-help" and exercises, forms of counseling and guidance, manuals and instructive literature, courses and retreats, etc., in which subjects engage in problematizing their current ways of living, and engage in other, more "healthy" life styles and attitudes.

From a Foucaultian perspective, such contemporary discourses and practices cannot simply be reduced to late modern de-traditionalization, secularization, privatization, and individualization processes. In fact, what Foucault's analyses suggest is that the characteristics of contemporary spirituality/spiritualité can be seen as modifications of a spiritual tradition in the West: the antique ideals of self-mastery and self-stylization, the problematizing hermeneutics of inner life, the spiritual counter-conducts, and the critique of power-knowledge regimes, the contemporary reconfigurations of subjectivation relative to the obligation "to truly live your life as meaningful and intense as possible". What we find here is not a rise of individualized and privatized religiousness on the ruins of a fragmented and outdated religious tradition, but much more new constellations of the relation between individual spiritual practices and a variety of religious and secular discourses, social environments, and institutions that, while partly overlapping and complementing each other, compete with each other over the favors and control of individuals. ${ }^{3}$

Funding: This research received no external funding.

Conflicts of Interest: The author declares no conflict of interest.

2 This is also the case in the discourse on spiritualite, although here the aim is to find a new cohesion between Christian spiritual practices/experiences and the official church doctrine.

3 Compare also footnote 1. 


\section{References}

Aupers, Stef, and Dick Houtman. 2008. The Sacralisation of the Self: Relocating the Sacred on the Ruins of Tradition. In Religion beyond a Concept. Edited by Hent de Vries. New York: Fortham University Press, pp. 798-812.

Bregman, Lucy. 2014. The Ecology of Spirituality. Meanings, Virtues, and Practices in a Post-Religious Age. Waco: Baylor University Press.

Foucault, Michel. 1972. The Archaeology of Knowledge and The Discourse on Language. New York: Vintage Book.

Foucault, Michel. 1990. The Care of the Self: The History of Sexuality Volume 3. London: Penguin.

Foucault, Michel. 1992. The Use of Pleasure: The History of Sexuality Volume 2. London: Penguin.

Foucault, Michel. 1997a. On the Genealogy of Ethics: An Overview of Work in Progress. In Ethics, Subjectivity and Truth. Edited by Paul Rabinow. New York: The New Press, pp. 253-80.

Foucault, Michel. 1997b. What is Enlightenment? In Ethics, Subjectivity and Truth. Edited by P. Rabinow. New York: The New Press, pp. 303-19.

Foucault, Michel. 1998a. The Will to Knowledge: The History of Sexuality Volume 1. London: Penduin.

Foucault, Michel. 1998b. Theatrum Philosophicum. In Aesthetics, Method and Epistemology. Edited by James D. Faubion. New York: The New Press, pp. 343-68.

Foucault, M. 1998c. My Body, this Paper, this Fire. In Aesthetics, Method and Epistemology. Edited by James D. Faubion. New York: The New Press, pp. 393-417.

Foucault, Michel. 1999a. About the Beginnings of the Hermeneutics of the self. In Religion and Culture: Michel Foucault. Edited by Jeremy Carrette. New York and Londen: Routledge, pp. 158-81.

Foucault, Michel. 1999b. The Battle for Chastity. In Religion and Culture: Michel Foucault. Edited by Jeremy Carrette. New York and Londen: Routledge, pp. 188-97.

Foucault, Michel. 2003. Abnormal. Lectures at the Collège de France 1974-1975. New York: Picador.

Foucault, Michel. 2005. The Hermeneutics of the Subject. Lectures at the College de France 1981-1982. New York: Picador. Foucault, Michel. 2007. Security, Territory, Population. Lectures at the Collège de France 1977-1978. New York: Picador. Foucault, Michel. 2011. The Courage of Truth. Lectures at the Collège de France 1983-1984. New York: Picador.

Foucault, Michel. 2017. Subjectivity and Truth. Lectures at the Collège de France 1980-1981. Londen: Pagrave MacMillan. Foucault, Michel. 2018. Histoire de la sexualité IV: Les aveux de la chair. Parijs: Gallimard.

Gauchet, Michel. 1997. The Disenchantment of the World. A Political History of Religion. Princeton: Princeton University Press.

Heelas, Paul. 1996. The New Age Movement: The Celebration of the Self and the Sacralisation of Modernity. Oxford: Blackwell. Heelas, Paul, and Linda Woodhead. 2005. The Spiritual Revolution: Why Religion is Giving Way to Spirituality. Oxford: Blackwell.

Houtman, Dick, and Paul Tromp. 2018. Post-Christian Spirituality: Misconceptions, Obstacles, Prospects. In Assessing Spirituality and Religion in a Diversified World: Beyond the Mainstream Perspective. Edited by Amy Ai, Kevin Harris and Paul Wink. New York: Springer, Available online: https://www.dickhoutman. nl/home/11 (accessed on 7 December 2018).

Houtman, Dick, Stef Aupers, and Willem De Koster. 2011. Paradoxes of Individualization: Social Conrol and Social Conflict in Contemporary Modernity. Burlington: Ashgate.

Kugelmann, Robert. 2011. Psychology and Catholicism. Contested Boundaries. Cambridge: Cambridge University Press. Mercadante, Linda A. 2014. Belief without Borders: Inside the Minds of the Spiritual but Not Religious. Oxford: Oxford University Press.

Oksala, Johanna. 2005. Foucault on Freedom. Cambridge: Cambridge University Press.

Streib, Heinz. 2008. More Spiritual than Religious: Changes in the Religious Field require new Approaches. In Lived Religion: Conceptual, Empirical and Practical-Theological Approaches. Edited by Heinz Streib, Astrid Dinter and Kerstin Söderblom. Leiden: Brill, pp. 53-67.

Streib, Heinz, and Ralph W. Hood. 2011. "Spirituality" as Privatized Experience-Oriented Religion: Empirical and Conceptual Perspectives. Implicit Religion 14: 433-53. [CrossRef]

Talar, Charles J. T., ed. 2009. Modernists and Mystics. Washington: The Catholic University of America Press.

Taylor, Charles. 2007. A Sexular Age. Cambridge: Harvard University Press.

Taylor, Charles. 2008. The Future of the Religious Past. In Religion beyond a Concept. Edited by H. de Vries. New York: Fordham University Press, pp. 178-244. 
Westerink, Herman. 2016. The Discontinuous History of the Psychology of Religion and Its Moving Target. In $A$ Hundred Years of the IAPR. A Celebratory Supplement to the Archive for the Psychology of Religion. Edited by Jabob Belzen. Leiden: Brill, pp. 78-95. 